\title{
MECHANICAL BEHAVIOR OF VOLCANIC ASH SOILS MIXED WITH SHREDDED TIRES
}

\author{
Daniel Aristizabal*, Gloria Molina \\ Faculty of Engineering, Universidad Libre Seccional Pereira, Colombia
}

Thanks to the efforts of different public and private entities, recent years have seen a growing interest in protecting the environment and in the use of non-renewable natural resources such as tires. One of the most widely accepted ways of using non-perishable materials has been their application in the construction of civil works. This paper focuses on the assessment of test tubes made up with mixtures of fine-grained Volcanic Ash Soil and Shredded Tires (VAS-TDA) to be applied as an alternative material for low cost lightweight fills, that allow the use of the greatest quantity possible of tires. The physical and mechanical properties of specimens made with mixtures of soil and shredded tires were examined, varying the location of the site of soil extraction and tire size (Gravel Size- Sand and Gravel Size). It was determined that test tubes made up of $40 \%$ medium-sized shredded tires and $60 \%$ soil, reached low dry density values, and that increasing the content of shredded tires leads to greater plasticity and less compressibility. Similarly, resistance diminishes but only up to Californian Bearing Ratio (CBR) values appropriate for use in the nucleus and foundation of an embankment. For test tubes with a maximum content of $15 \%$ of type 2 shredded tires, there appeared to be little reduction in the resistance to the mixture, as long as a compaction energy of $2700 \mathrm{kN}-\mathrm{m} / \mathrm{m}^{3}$ is applied.

Key words: ash soils, shredded tires, mechanical behavior, material mixture test

\section{INTRODUCTION}

The problem of environmental pollution generated by tires is known worldwide, statistical data are found in the literature in which it is evident that these deposits represent billions of tons per year projected to 2025 [1-2]. They are often incorrectly stored and disposed of, these stocks represent a threat of uncontrolled fires and other environmental risks [3]. Therefore, efforts are currently focused on investigating the reuse of these materials due to their non-biodegradable characteristic.

The dumping of whole tires in landfills has been banned since 2003 as has their incineration without energy recovery. In January 2006, dumping shredded tires in landfills was also banned [4]. This has meant that the market for shredded tires for applications in civil engineering has increased slightly over the last decade. Some data obtained indicate that approximately 12 million shredded tires (0.13 million metric tons) in 1995 and 15 million (0.17 million metric tons) in 1996, were used for civil works that include slurries in collection systems, landfill covers, infills for road embankments, roadbeds and similar works [5].

One of the most commonly used recycling options in countries such as the United States and Canada is the use of shredded tires alone or mixed with some type of soil, as infills for embankments and in retaining walls, known as Tire-Derived Aggregate or TDA. This method has been used satisfactorily for embankments in North America since the beginning of the 1990s [6]. In Canada, it was first used in 2000 to construct 300 longitudinal meters of embankment on soft ground [7]. Since then, it has been considered a low-cost solution, which is frequently applied in cases where infill weight has to be reduced in order to guarantee stability in the construction.

One of the advantages of this material is that its unitary weights are 5.5 and $6.4 \mathrm{KN} / \mathrm{m}^{3}$ [8], which is useful in the construction of civil works on roads built on low load-bearing capacity compressible soils where the stability and settlements are the more critical aspects. it is also non-biodegradable, of long-duration and resistant to biological agents. The cost of shredded tires in countries such as the US, varies between 5 to 50 dollars per $\mathrm{m}^{3}$ depending on the quality; in Colombia, it varies between 195 and 231 dollars depending on its granulometry.

A number of studies carried out around the world, have revealed the behavior of shredded tires. Hataf reported the elaboration of mixtures of sand and shredded tires of different sizes and in different volume percentages [9], concluding that the greater the percentage of shredded tires, the greater the load-bearing capacity(concluding that the load-bearing capacity is proportional to the percentage of shredded tires). Edinçliler and his group, on the other hand, compared the behavior of different sizes of tire shreds or pieces after recycling and mixing them with sand, confirming that adding TDA to sand increases its cutting resistance, recording friction angle values of above $65^{\circ}[10]$. Cano and collaborators [11] conducted in-field assessments of soil with shredded tires, concluding that these were more dense, less deformable, and more easily compactable. Li and collaborators measured the effect of the tire load-bearing zones in a smallscale sand embankment. In this project, we define the reduction of stress transmission to lower layers due to 
the confinement generated by reinforcement and a $50 \%$ reduction of the settlement rate when compared to an embankment without reinforcement [12].

Investigations confirm the high compressibility of the remains of tires, a characteristic that increases the settlement rate and may lead to faults in the embankments [13]. Hidalgo and his group mixed shredded tires with sub-base granular material finding a reduction of the load-bearing capacity between the mixture and the subbase layer. These studies confirm the importance of assessing this problem especially in loam-texture volcanic ash soils [14].

A number of authors have been interested in the influence of tire components in soils, examining whether there is a significant influence on subsoil water and its structure due to the release of zinc, hydrocarbons, and aniline due to TDA. The results showed that the amount of these elements found in the soil did not exceed the environmental safety parameters [15]. The studies also referred to the possibility of combustion in exclusive shredded tire landfills not covered by a layer thick enough to protect the fill from ultraviolet rays and the incorporation of particles that could make the material ignite. However, as shown by Yoon, this problem can be solved by adding a percentage of soil or sand to the material. In addition to this, the sand mixture proved to be less compressible and more cutting resistant [16].

This study assesses the mechanical behavior of the TDA- volcanic ash soil mixture for application as a safe, low cost, lightweight fills, counteracting the results, compaction, and load-bearing capacity contained in the American Standard Test Methods (ASTM) guidelines for the use of shredded tires in civil engineering works.

\section{METHODOLOGY}

Laboratory assays were carried out to determine the physical and mechanical properties of the soil with which the shredded tires was going to be mixed, and to classify the tires used into two categories: shredded tires with diameters of between $0.075 \mathrm{~mm}$ and $19 \mathrm{~mm}$, and shredded tires with diameters of $25.4 \mathrm{~mm}$.

The methodology was divided into the following phases: Phase 1. Physical and mechanical characterization of the materials by applying the following tests: dry and wet sieve analysis (ASTM-D 421-85(2007) [17], ASTM D 2217-85 (1998) [18]), liquid limit and plastic limit tests and Plasticity Index (ASTM D4318-17) [19], specific gravity (ASTM D 854-10) [20], Scanning electron microscopy SEM-EDX,Standard Test Methods for Measurement of Hydraulic Conductivity of Saturated Porous Materials Using a Flexible Wall Permeameter(ASTM D5084-16a) [21], constant head permeability for tires (ASTM D 243468) [22], resistance to degradation of coarse aggregate (ASTM C 535-09) [23], and soundness of aggregate by use of sodium sulfate or magnesium sulfate (ASTM C 88-05) [24].

Phase 2. Evaluation of the behavior of VAS/TDA mixtures involving the production of mixtures with different percentages of volcanic ash soil (VAS) and shredded tires TDA. Two types of treatment were designed for this procedure.

Treatment 1: VAS1/TDA1, in which TDA1 corresponds to a PG texturematerial in proportions of $10 \%, 20 \%, 30 \%$, and $40 \%$.

Treatment 2: VAS2/TDA2, in which TDA2 corresponds to a PG material in proportions of $5 \%, 10 \%$, and $15 \%$.

\section{RESULTS}

Characterization of materials: Volcanic ash soil deposits in Colombia cover around $11.6 \%$ of the territory [25], and are found in the superficial layer of the stratigraphic profile with thicknesses of between 5.0 and $25.0 \mathrm{~m}$. Sensitivity analyses with these materials have shown that they

Table 1: Physical characterization of soil and tires

\begin{tabular}{|c|c|c|c|c|c|c|c|c|}
\hline Soil type & Treatment & $\begin{array}{l}\text { Liquid } \\
\text { Limit LL } \\
(\%)\end{array}$ & $\begin{array}{c}\text { Plastic } \\
\text { limit PL } \\
(\%)\end{array}$ & $\begin{array}{l}\text { Plasticity } \\
\text { Index } \\
\text { PI (\%) }\end{array}$ & $\begin{array}{c}\text { Specific } \\
\text { gravit Gs }\end{array}$ & $\begin{array}{c}\text { Percentage } \\
\text { retained on } \\
\text { the \#200 } \\
\text { sieve (\%) }\end{array}$ & $\begin{array}{c}\text { Passing } \\
\text { through the } \\
\# 200 \text { sieve } \\
(\%)\end{array}$ & $\begin{array}{c}\text { USCS } \\
\text { Classification } \\
\text { (ASTM D } \\
2487-11)\end{array}$ \\
\hline 1 & 1 & 36.40 & 30.25 & 6.15 & 2.66 & 5.00 & 95.00 & $\mathrm{ML}^{*}$ \\
\hline 2 & 2 & 49.66 & 34.74 & 14.91 & 2.53 & 11.30 & 88.70 & $M L$ \\
\hline Type of tire & Treatment & $\begin{array}{l}\text { Passing } \\
\text { through } \\
\text { the } 3 / 4 " \\
\text { sieve (\%) }\end{array}$ & $\begin{array}{c}\text { Passing } \\
\text { through } \\
\text { the \#4 } \\
\text { sieve } \\
(\%)\end{array}$ & $\begin{array}{l}\text { Passing } \\
\text { through } \\
\text { the \# } 200 \\
\text { sieve (\%) }\end{array}$ & $\begin{array}{l}\text { Coefficient } \\
\text { of } \\
\text { curvature } \\
\text { Cc }\end{array}$ & $\begin{array}{c}\text { Uniformity } \\
\text { coefficient } \\
\mathrm{Cu}\end{array}$ & $\begin{array}{c}\text { USCS } \\
\text { Classification } \\
\text { (ASTM D } \\
2487-11 \text { ) }\end{array}$ & $\begin{array}{c}\text { Percentage of } \\
\text { wearl } \\
\text { Soundness of } \\
\text { Aggregates by } \\
\text { Use of } \\
\text { Sodium } \\
\text { Sulfate } \\
\end{array}$ \\
\hline $\begin{array}{c}\text { Type } 1 \text { Gravel } \\
\text {-Sand }\end{array}$ & 1 & 98.00 & 44.70 & 1.20 & 0.29 & 28.57 & GP & --- \\
\hline Type 2 Gravel & 2 & 100.00 & 0.00 & 0.00 & 0.00 & 0.00 & GP & $0 / 0$ \\
\hline
\end{tabular}

* Low compressibility loam 


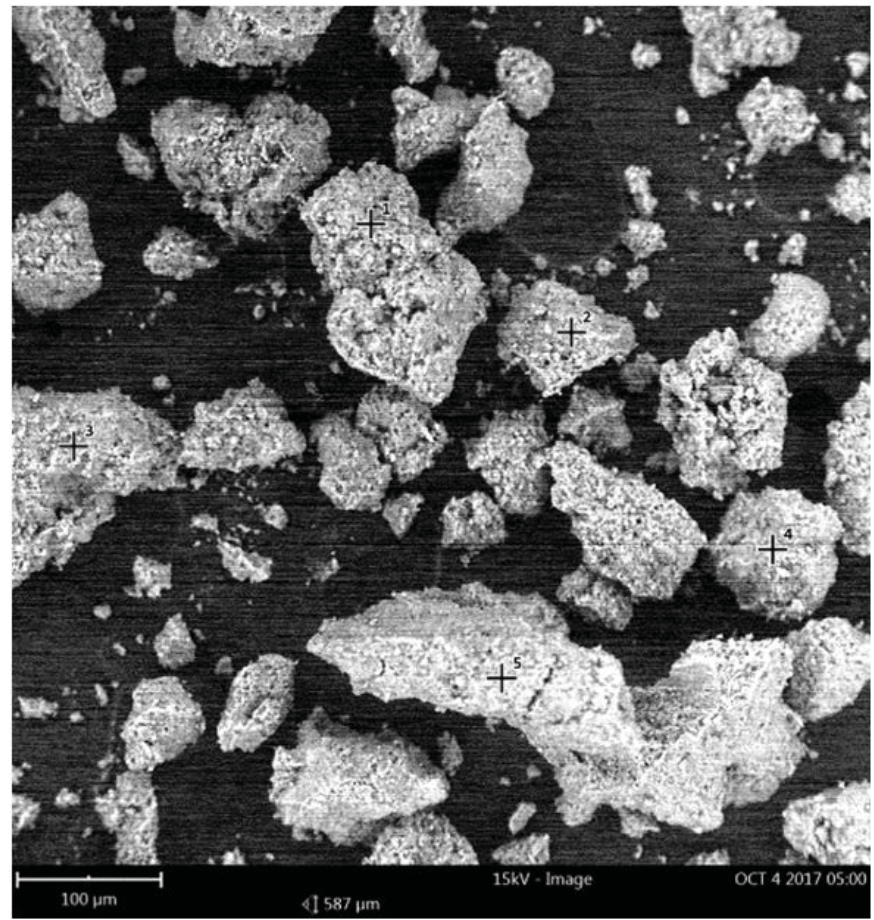

Figure 1: Scanning electron microscopy 100 um and atomic force microscopy 10 um images
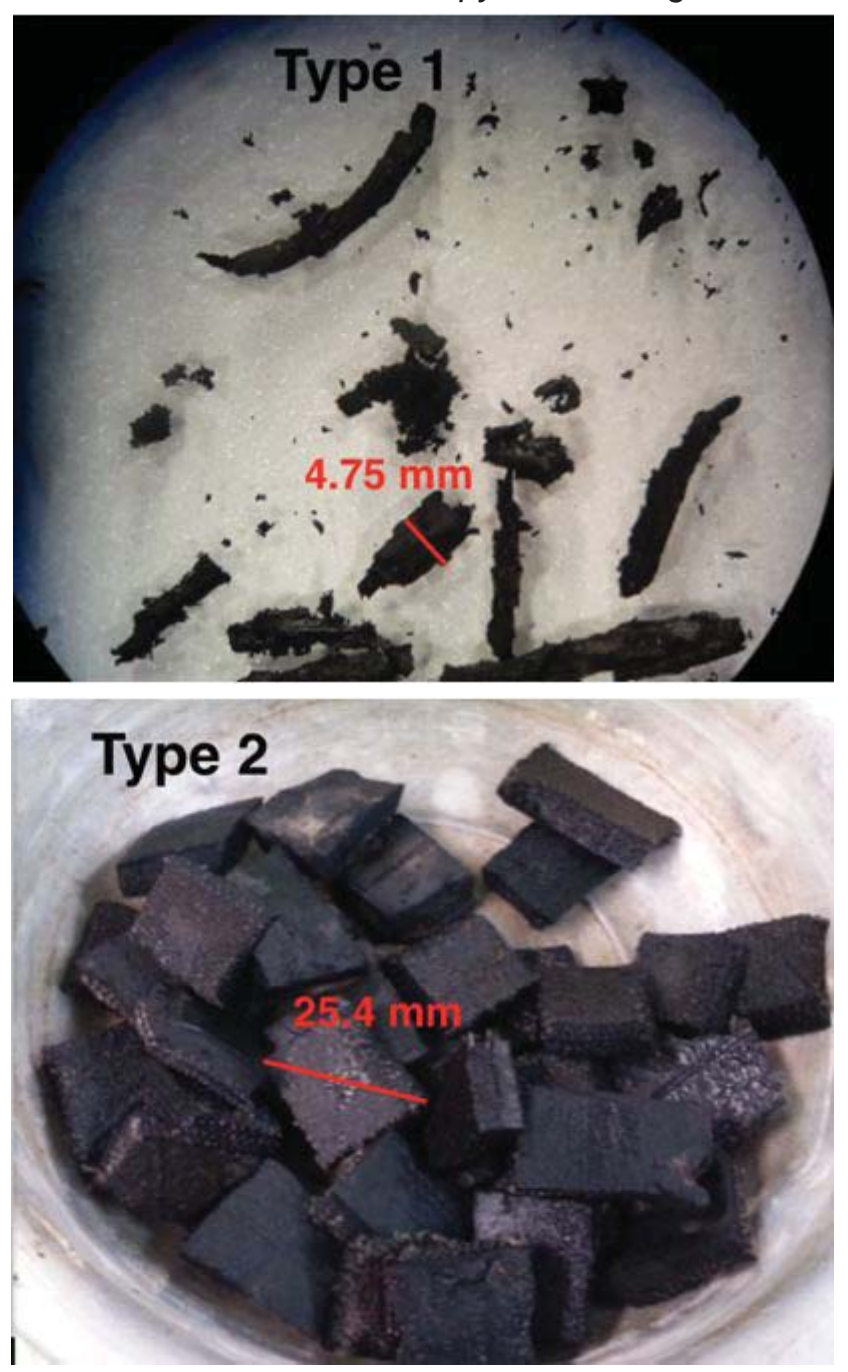

Figure 2: Images of shredded tires do not present this problem. Table 1 shows the physical analyses carried out with the volcanic ash soils used in this study.

The shredded tires used in this study, were designated as Shredded Type 1 tire and Shredded Type 2 tire in sizes equal to $25.4 \mathrm{~mm}$ based on tires from heavy machinery, Table 1 and Figure 2 present the properties of the materials

Scanning electron microscopy SEM EDX and atomic force microscopy AFM were conducted on air-dried soil samples (Figure 1), identifying the chemical composition of the particles of VAS1 soil. The chemical concentration of the soil particles in air-dried samples was identified. The chemicals found in the highest concentrations were the following: carbon $16 \%$, aluminum $13 \%$, silica $12 \%$, and iron $6 \%$.

\section{MATERIAL MIXTURE TESTS}

By increasing the percentages of shredded tires in a mixture in treatment 1, the LL and PI values(either) diminish or are kept constant. For $40 \%$ shredded tires, a liquid limit of $28.54 \%$ was obtained, $24.61 \%$ (with standard deviation $0.48 \%$ ) plastic limit, and a Plasticity Index of $3.93 \%$. These values describe the same soil type but with low plasticity, reflecting a reduction of the compressibility, because the material is considered appropriate and better for landfills. This behavior favors the material's use as subgrade for a road, which requires a subsoil of $\mathrm{PI}<4$.

Shredded tires constitute a light-weight material with a density of 2.7 a $7.0 \mathrm{kN} / \mathrm{m}^{3}$ [26] according to the other investigations. The maximum dry density for the TDA used in this study corresponds to a value of $7.16 \mathrm{kN} / \mathrm{m}^{3}$, the maximum dry density for Soil 1 is $11.67 \mathrm{kN} / \mathrm{m}^{3}$ and for Soil 2, of $12.26 \mathrm{kN} / \mathrm{m}^{3}$. When the soil was mixed with TDA in both treatments, the dry density reduced as the percentage of shredded tire increased. With 40\% TDA/ VAS, the maximum dry density reduces by $13 \%$ with respect to the density value for the soil in its initial state.

The soils used in this project are sandy clay, which are characterized by their low permeability. The average permeability coefficient $(K)$ obtained was $7.02 \times 10-6 \mathrm{~cm} / \mathrm{s}$ with standard deviation $1.76 \times 10-6 \mathrm{~cm} / \mathrm{s}$, which is a value that characterizes loam clay materials [27]. Additionally, fine-grained soils retain more moisture than coarse-grained soils and hence, the importance of guaranteeing adequate drainage in the construction of landfills with excavation materials. In contrast, shredded tires presented $\mathrm{K}$ values in the interval of $1.6 \times 10-2 \mathrm{a}$ $7.6 \times 10-2 \mathrm{~cm} / \mathrm{s}$. By adding TDA to the soil a smaller contact area between particles is created where less water is retained and the infiltration velocity increases, improving the soil's properties of hydraulic conductivity. The results showed that the larger the percentage of TDA, the greater the permeability coefficient. As shown in Figure 3 , a permeability coefficient of $4.90 \times 10-3 \mathrm{~cm} / \mathrm{s}$ (with standard deviation $6.56 \times 10-4 \mathrm{~cm} / \mathrm{s}$ ) was obtained for the mixture containing $40 \%$ TDA, this treatment has sig- 


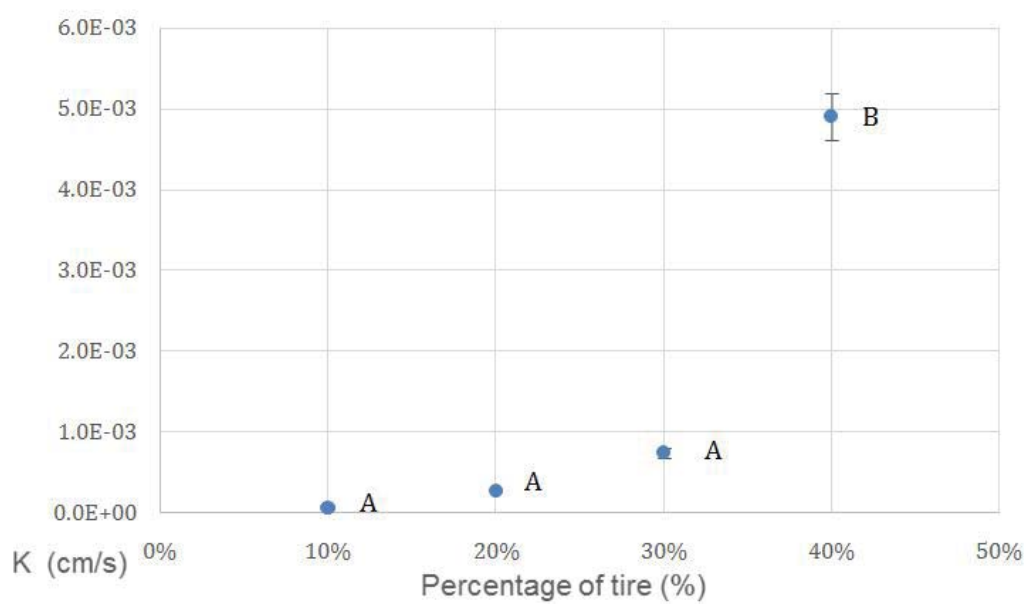

Figure 3: Permeability of the samples with different percentages of shredded tire. Test LSD Fischer, DMS 0,000192. Different letters represent significant differences between treatments

nificant statistical differences, according to the test LSD Fischer.

\section{Compaction and resistance test}

To test the mechanical properties,in this test a standard deviation between the values of $0,08 \mathrm{kN} / \mathrm{m}^{3}-1,29 \mathrm{kN} / \mathrm{m}^{3}$ for test type 1, and standard deviation between the values of $0,03 \mathrm{kN} / \mathrm{m}^{3}-0,45 \mathrm{kN} / \mathrm{m}^{3}$ for test type 2 , the soil's response to compaction and resistance was compared with varying percentages of tire on the mix was compared.

For the different solid types Soil type 1 /Tire type 1, we can see a reduction of the maximum dry density of $13 \%$, and $25 \%$ for the optimum moisture with a tire content of $40 \%$. For Soil mixture types 2/Tire Type 2, there was a reduction of the maximum dry density of $10 \%$, and of $7 \%$

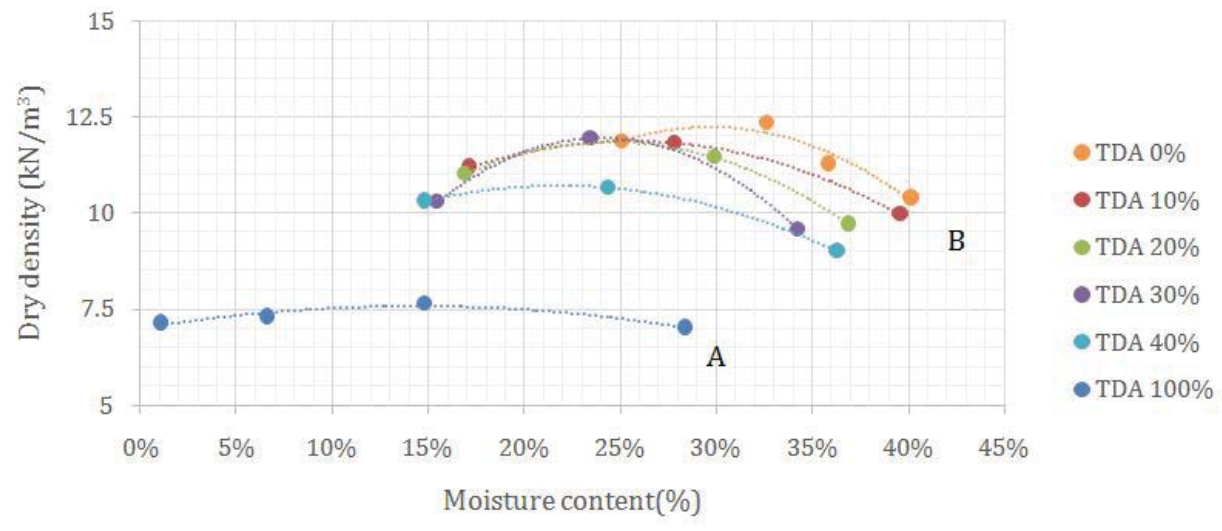

Figure 4: Variation in the behavior depending on the compaction of the soil/tire mixtures in treatment 1.

Standard error $\left(0.37-0.76 \mathrm{kN} / \mathrm{m}^{3}\right)$. Test LSD Fischer DMS 0,183. Different letters represent significant differences between treatments

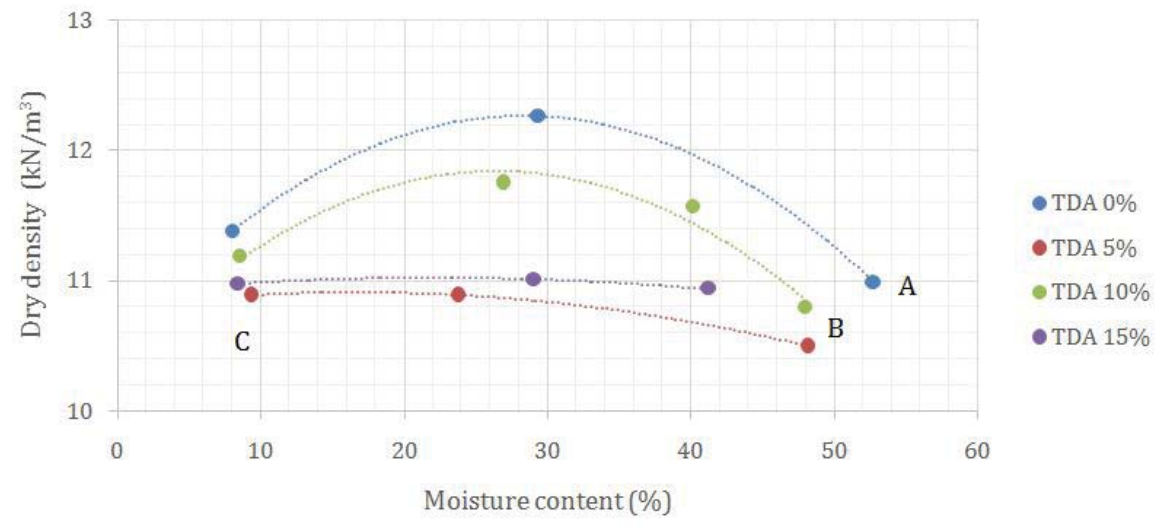

Figure 5: Variation in the behavior depending on the compaction of the soil/tire mixtures in treatment 2.

Standard error $\left(0.02-0.26 \mathrm{kN} / \mathrm{m}^{3}\right)$. Test LSD Fischer DMS 0,549. Different letters represent significant differences between treatments 


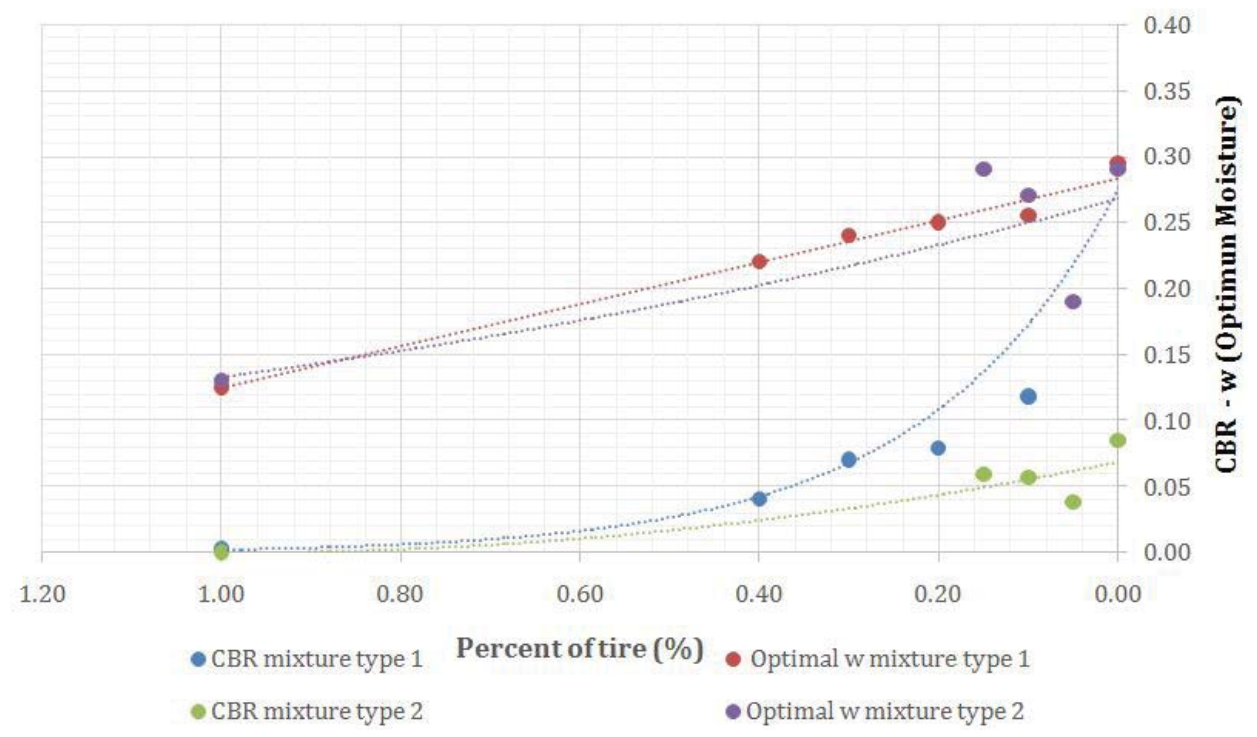

Figure 6: CBR values in optimum moisture with respect to the percentage of tire in the mixture

for the optimum moisture with a tire content of $15 \%$ in Treatment 2. Figure 4 and Figure 5 show the behavior of the soil mixtures with different percentages of shredded tire.

The behavior of soil mixtures Soil type 1/Tire type 1 demonstrated that the addition of shredded tire to the soil reduces its density but at the same time its resistance. The CBR value for the soil was of $52.00 \%$ (w: $29.50 \%$ ). These values are appropriate for these materials to be used in the construction of all parts of embankments (foundation, nucleus and crown), whereas for 40\% TDA1 and $60 \%$ VAS, the CBR value was $4 \%$ (w: $22 \%$ ), which is considered adequate for the construction of embank-

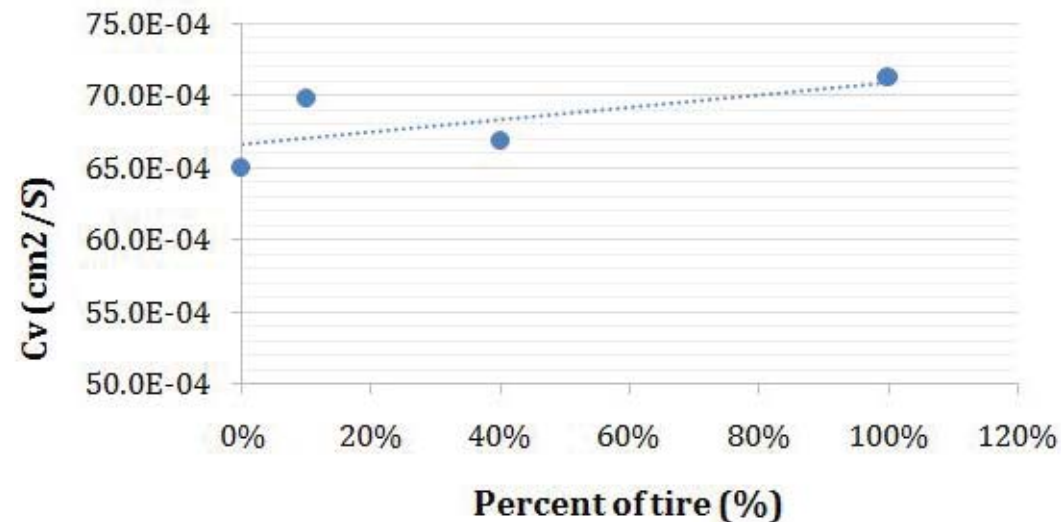

Figure 7: Behavior of the consolidation coefficient in relation to the percentage of shredded tire added to the mixture. Standard deviation (5.29-6.99 $\left.\times 10-4 \mathrm{~cm}^{2} / \mathrm{s}\right)$ standard error $\left(2.37-3.30 \times 10-4 \mathrm{~cm}^{2} / \mathrm{s}\right)$

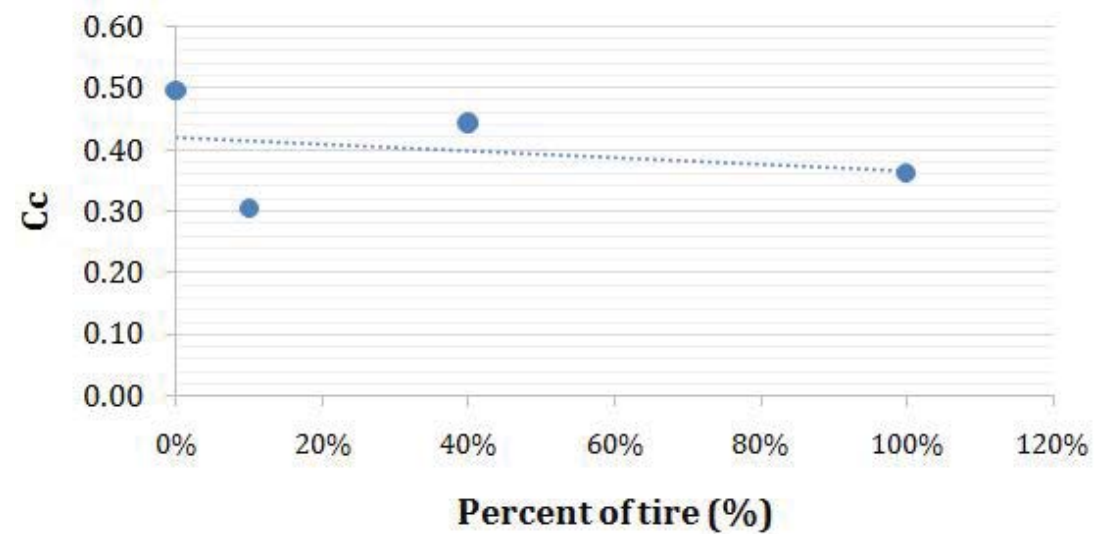

Figure 8: Behavior of the coefficient of compression in relation to the percentage of shredded tire added to the mixture 
ments although only for the foundation layers and nucleus, according to specifications of construction [28]. The behavior of the resistance of the mixtures of Soil type $2 /$ Tire type 2, was similar, although soil resistance in this case was below a CBR of $8.5 \%$ (w: $29 \%$ ), and for the $15 \%$ TDA, $85 \%$ VAS mixture, a CBR of $5.9 \%$ (w:29\%) was found. Figure 6 shows the variations in the resistance of the soil-tire mixtures. It is observed that the addition of the crushed tire decreases the optimum moisture content value.

The VAS1 soil has a consolidation coefficient $(\mathrm{Cv})$ of $65 \times 10-4\left(\mathrm{~cm} / \mathrm{s}^{2}\right)$, which presents a relative increase when TDA is added to the mixture as shown in Figure 7. With $40 \%$ TDA, a value of $66.8 \times 10-4\left(\mathrm{~cm} / \mathrm{s}^{2}\right)$ is reached indicating that the consolidation time in mixtures with TDA is reduced when compared to pure soil. This is considered favorable for construction given that when consolidation requires unacceptable timeframes, methods are required that can accelerate the process [29].

The compression coefficient was also studied indicating that soil compressibility (Cc), which, for the material without TDA, is of 0.49 , which corresponds to clay loam, and it reduces relatively when adding different percentages of shredded tires as shown in Figure 8, for $40 \%$ TDA, whereby a Cc of 0.44 was obtained, indicating that the settlement rate of the embankments built with this material, would be of lesser magnitude than those of embankments built using VAS from excavations. This is favorable for constructions given that, as the settlement rate is decreased, stability is ensured. The behavior observed in the consolidation process is similar to that of coarse material, whereby the material suffers an initial deformation for a short time followed by a relatively stable secondary consolidation.

\section{CONCLUSIONS}

It is possible and favorable to use mixtures of shredded tires and soil derived from loam texture volcanic ash $\mathrm{MH}$ -as long as these materials are not sensitive and do not collapse- to build embankments or landfills following the specifications of global norms related to the minimum CBR value of the materials and of norm ASTM D6270-98 (2004), for the use of tires.

The behavior studied of the different percentages of mixtures presents benefits insofar as greater permeability and speed of consolidation, decreased rate of settlement, lower unitary weight, and a great contribution to the protection of the environment when compared to the use of pure VAS. According to the results obtained, the most suitable ratio appears to be $40 \%$ TDA and 60\%VAS. The load-bearing capacity CBR of the loam soil reduces as TDA is added, limiting the percentage of tire that can be added to the mixture of these materials. However, the greater the size of the shredded tires, the lower the resistance of the mixture, according to this, tire sizes smaller than $1 \mathrm{~cm}$ are recommended.

\section{ACKNOWLEDGEMENTS}

The authors thank Tecnoparque Pereira and TecnoAcademia Pereira for their technical and instrumental support.

\section{REFERENCES}

1. Symeonides, D., Loizia, P. \&Zorpas, (2019). Tire waste management system in Cyprus in the framework of circular economy strategy. A.A. Environ Sci Pollut Res, 1-16

2. Pathway Polymers. (2012). Sustainability in the Tire Industry.

3. IOP Conf. Series: Materials Science and Engineering 385 (2018) 012057 doi:10.1088/1757$899 \times / 385 / 1 / 012057$ The potential utilization of the rubber material after waste tire recycling $\mathrm{J}$ Svoboda 1,2, V Vaclavik1,2, T Dvorsky1 , L Klus1,2 and R Zajac1

4. Mateos, T., \& Garc, O. (n.d.). Construcción de un terraplén de carretera con neumáticos fuera de uso (NFU).

5. Liu, H. S., Mead, J. L., \&Stacer, R. G. (2000). Environmental Effects of Recycled Rubber in Light-Fill Applications. Rubber Chemistry and Technology, 73(3), 551-564. https://doi.org/10.5254/1.3547605

6. Mills, B., Naggar, H. El, \&Valsangkar, A. (2015). Chapter 22 - North American Overview and a Canadian Perspective on the Use of Tire-Derived Aggregate in Highway Embankment Construction A2 - Indraratna, Buddhima. In J. Chu \& C. B. T.-G. I. C. H. Rujikiatkamjorn (Eds.) (pp. 635-655). San Diego: Butterworth-Heinemann. https://doi.org/https://doi. org/10.1016/B978-0-08-100698-6.00022-2

7. Shalaby, A., \& Ahmed Khan, R. (2002). Temperature Monitoring and Compressibility Measurement of a Tire Shred Embankment: Winnipeg, Manitoba, Canada. Transportation Research Record: Journal of the Transportation Research Board, 1808, 67-75. https://doi.org/10.3141/1808-08

8. Elias, V., Welsh, J., WARREN, J., \& Lukas, R. (2000). Ground Improvement Technical Summaries - Vol. 1 and 2. Federal Highway Administration.

9. Hataf, N., \& Rahimi, M. M. (2006). Experimental investigation of bearing capacity of sand reinforced with randomly distributed tire shreds. Construction and Building Materials, 20(10), 910-916. https://doi. org/10.1016/j.conbuildmat.2005.06.019

10. Edinçliler, A., Baykal, G., \&Saygili, A. (2010). Influence of different processing techniques on the mechanical properties of used tires in embankment construction. Waste Management, 30(6), 1073-1080. https://doi.org/10.1016/j.wasman.2009.09.031 
11. Cano, H., Estaire, J., \&Rodríguez, R. (2011). Terraplénexperimentalconstruido con neumáticostroceados. In Jornadatécnica sobre experienciasrecientes en estructuras de tierra para infraestructurasviarias (p. 11).

12. Li, L., Xiao, H., Ferreira, P., \& Cui, X. (2016). Study of a small scale tyre-reinforced embankment. Geotextiles and Geomembranes, 44(2), 201-208. https:// doi.org/10.1016/j.geotexmem.2015.08.004

13. Aderinlewo, O., \& Okine, N. A. (2009). Sensitivity analysis of a scrap tire embankment using Bayesian influence diagrams. Construction and Building Materials, 23(3), 1446-1455. https://doi.org/10.1016/j. conbuildmat.2008.07.003

14. Hidalgo Signes, C., Martínez Fernández, P., MedelPerallón, E., \&Insa Franco, R. (2015). Characterisation of an unbound granular mixture with waste tyre rubber for subballast layers. Materials and Structures/Materiaux et Constructions, 48(12), 3847-3861. https://doi.org/10.1617/s11527-0140443-z

15. Zornberg, J. G., Cabral, A. R., \&Viratjandr, C. (2004). Behaviour of tire shred \&\#150; sand mixtures. Canadian Geotechnical Journal, 41(2), 227-241. https:// doi.org/10.1139/t03-086

16. Yoon, S. (2006). Mechanical response of tire shredsand mixtures and applications to geotechnical structures. Purdue University.

17. ASTM International. (2007). ASTM D421-85. Standard Practice for Dry Preparation of Soil Samples for Particle-Size Analysis and Determination of Soil Constants.

18. ASTM International. (1998). ASTM D 2217-85. Standard Practice for Wet Preparation of Soil Samples for Particle-Size Analysis and Determination of Soil Constants.

19. ASTM International. (2017). ASTM D4318-17. Standard Test Methods for Liquid Limit, Plastic Limit, and Plasticity Index of Soils.

20. ASTM International. (2010). ASTM D854-10. Standard Test Methods for Specific Gravity of Soil Solids by Water Pycnometer.
21. ASTM International. (2006). ASTM D5084-16a. Standard Test Methods for Measurement of Hydraulic Conductivity of Saturated Porous Materials Using a Flexible Wall Permeameter.

22. ASTM International. (2006). ASTM D2434-68. Standard Test Method for Permeability of Granular Soils.

23. ASTM International. (2009). ASTM C535-09. Standard Test Method for Resistance to Degradation of Large-Size Coarse Aggregate by Abrasion and Impact in the Los Angeles Machine.

24. ASTM International. (2005). ASTM C 88-05. Standard Test Method for Soundness of Aggregates by Use of Sodium Sulfate or Magnesium Sulfate.

25. Lizcano, A., \& Herrera, M. C. (2006). Suelos derivados de cenizas volcánicas en Colombia. Rev. Int. de Desastres Naturales, Accidentes E Infraestructura Civil, 6(2), 167-198.

26. Humphrey, D., \& Manion, W. (1992). Properties of tire chips for lightweight fill. InProceedings of the Conference on Grouting, Soil Improvement and GeosyntheticsGeotechnical Special (pp. 1344-1355). New York

27. Yura, M. (2014). Propiedadeshidráulicas del suelo.

28. U.S. Department of the Navy, Foundations and Earth Structures, DesignManual 7.2, Naval Facilities Engineering Command, Alexandria, VA, 1982.

29. Orlando, F., \& Cubillos, G. (2007). Análisis de asentamientos secundarios en los suelos de la zona del Lago en la ciudad de Bogotá D.C. Universidad de la Salle.
Paper submitted: 11.06.2019.

Paper accepted: 10.12.2019.

This is an open access article distributed under the CC $B Y-N C-N D 4.0$ terms and conditions. 